Kumawula, Vol. 3, No.3, Desember 2020, Hal 500 - 506 DOI: https://doi.org/10.24198/kumawula.v3i3.29734

ISSN 2620-844X (online)

Tersedia online di http://jurnal.unpad.ac.id/kumawula/index

\title{
SOSIALISASI MANAJEMEN KINERJA TENAGA KESEJAHTERAAN KECAMATAN DALAM PENANGGULANGAN MASALAH KESEJAHTERAAN SOSIAL DI KECAMATAN KARAWANG BARAT
}

\author{
Hanny Purnamasari ${ }^{1^{*}}$, Rachmat Ramdani ${ }^{2}$ \\ ${ }^{1}$ Universitas Singaperbangsa Karawang \\ ${ }^{2}$ Universitas Singaperbangsa Karawang \\ *Korespondensi : hanny.purnamasari@fisip.unsika.ac.id
}

\begin{abstract}
Social problems in society such as poverty, neglect, social disability and deviant behavior encourage the government to immediately take action through an integrated and systematic approach in order to reduce social welfare problems and meet the basic needs of the citizens properly. This encourages to socialize the performance management of the sub-district social welfare workers in overcoming social welfare problems in West Karawang District. This community service aims to explain and provide an understanding of the performance management of welfare personnel in addressing social welfare problems. This method of community service is carried out by conducting socialization which will be held in the hall of West Karawang District, Karawang Regency. The presentation of the material was delivered by the service implementer who is the teaching staff of the Governmental Science Study Program, Singapore University, Karawang. Welfare workers are expected to participate actively in relation to the topic by opening a question and answer session.
\end{abstract}

Keywords: socialization ; work management ; district health workers; West Karawang

\begin{abstract}
ABSTRAK
Permasalahan sosial di tengah masyarakat seperti kemiskinan, keterlantaran, ketunaan sosial dan penyimpangan perilaku mendorong pemerintahan untuk segera mengambil tindakan untuk penanganan melalui pendekatan secara sistematis terpadu dan menyuluruh dalam rangka mengurangi permasalahan kesejahteraan sosial serta memenuhi kebutuhan dasar warga negara secara layak. Hal ini mendorong untuk melakukan sosialisasi manajemen kinerja tenaga kesejahteraan sosial kecamatan dalam penanggulangan masalah kesejahteraan sosial di Kecamatan Karawang Barat. Pengabdian kepada masyarakat ini bertujuan untuk menjelaskan dan memberikan pemahaman tentang manajemen kinerja tenaga kesejahteraan dalam penanggulangan masalah kesejahteraan sosial. Metode pengabdian kepada masyarakat ini dilakukan dengan melakukan sosialisasi yang akan dilaksanakan di aula Kecamatan Karawang Barat Kabupaten Karawang. Pemaparan materi disampaikan oleh pelaksana pengabdian yang merupakan staf pengajar Program Studi Ilmu Pemerintahan Universitas Singaperbangsa Karawang. Tenaga kesejahteraan diharapkan berpartisipasi aktif terkait dengan topik dengan dibukanya sesi tanya jawab.
\end{abstract}

Kata kunci: sosialisasi ; manajemen kinerja ; tenaga kesehatan kecamatan; karawang barat

\section{PENDAHULUAN}

Penanggulangan permasalahan

kesejahteraan sosial yang berkaitan dengan kemiskinan memerlukan penanganan yang didasarkan pada partisipasi dari masyarakat yang bersangkutan sehingga penangganan permasalahan kemiskinan bersifat kontekstual sesuai dengan permasalahan yang terjadi di lapangan serta harus memahami betul bagaimana dengan budaya masyarakat tersebut serta kelembagaan pemerintahan yang menjadikan jembatan antara usaha pemerintah dalam menanggani permasalahan kesejahteraan. Dalam memfasilitasi permasalahan kesejahteraan sosial di 
Kabupaten Karawang, dibutuhkan manajemen yang baik bagi institusi publik dalam membangun relasi antara pemerintah dengan masyarakat dalam menyelesaikan masalah kesejahteraan sosial. Penulis melakukan kegiatan pengabdian pada masyarakat di Kecamatan Karawang Barat bermitra dengan tenaga kesejahteraan Sosial kecamatan. Kecamatan Karawang Barat merupakan kecamatan yang wilayahnya berada di pusat Kota, penulis melaksanakan kegiatan pengabdian pada masyarakat dengan melakukan sosialisasi manajemen kinerja pada tenaga kesejahteraan sosial kecamatan di Kecamatan Karawang Barat. Dalam menyampaikan materi mengenai sosialisasi manajemen kinerja tenaga kesejahteraan sosial kecamatan dalam menanggulangi masalah kesejahteraan sosial kecamatan penulis menggunakan pendekatan teoritis dari Desler (2003:322) memberikan definisi manajemen kinerja adalah proses mengkonsolidasikan penetapan tujuan, penilaian dan pengembangan kinerja ke dalam satu sistem tunggal bersama yang bertujuan untuk memastikan kinerja untuk mendukung dari tujuan strategis organisasi. Selanjutnya, menurut Costello (1994:3) menyatakan bahwa manajemen kinerja merupakan dasar dan kekuatan mendorong yang berada di belakang semua keputusan organisasi, usaha kerja dan alokasi sumber daya. Berdasarkan pengertian dari dua ahli di atas maka dapat dipahami bahwa manajemen kinerja adalah proses kegiatan untuk mencapai tujuan oroganisasi dengan mengembangkan alokasi sumber daya untuk mendukung dari tujuan strategis organisasi. Tahapan Manajemen Kinerja Menurut

Williams (1998), terdapat empat tahapan utama dalam pelaksanaan manajemen kinerja. Tahapan ini menjadi suatu siklus manajemen kinerja yang saling berhubungan dan menyokong satu dengan yang lain.

1. Tahap pertama: directing/planning. Tahap pertama merupakan tahap identifikasi perilaku kerja dan dasar/basis pengukuran kinerja. Kemudian, dilakukan pengarahan konkret terhadap perilaku kerja dan perencanaan terhadap target yang akan dicapai, kapan dicapai, dan bantuan yang akan dibutuhkan.

2. Tahap kedua: managing/supporting. Tahap kedua merupakan penerapan monitoring pada proses organisasi. Tahap ini berfokus pada manage, dukungan, dan pengendalian terhadap jalannya proses agar tetap berada pada jalurnya. Jalur yang dimaksudkan disini adalah kriteria maupun proses kerja yang sesuai dengan prosedur berlaku dalam suatu organisasi.

3. Tahap ketiga: review/appraising. Tahap ketiga mencakup langkah evaluasi. Evaluasi dilakukan dengan flashback/review kinerja yang telah dilaksanakan. Setelah itu, kinerja dinilai/diukur (appraising). Tahap ini memerlukan dokumentasi/record data yang berkaitan dengan obyek yang dievaluasi. Evaluator harus bersifat objektif dan netral agar didapat hasil evaluasi yang valid.

4. Tahap keempat: developing/rewarding. Tahap keempat berfokus pada pengembangan dan penghargaan. Hasil evaluasi menjadi pedoman penentu keputusan terhadap action yang dilakukan selanjutnya. Keputusan dapat berupa langkah perbaikan, pemberian reward/punishment, melanjutkan suatu kegiatan/prosedur yang telah ada, dan penetapan anggaran.

5. Dari tahapan manajemen kinerja di atas, kita dapat melihat bahwa manajemen kinerja yang optimal dapat tercapai apabila didukung oleh perencanaan (planning) yang matang, monitoring yang berkelanjutan, evaluasi dan pengembangan.

\section{METODE}

Metode yang digunakan dalam kegiatan pengabdian kepada masyarakat ini adalah pemberian materi Sosialisasi Manajemen Kinerja Tenaga Kesejahteraan Dalam Penanggulangan Masalah Kesejahteraan Sosial di Kecamatan Karawang Barat dengan menghadirkan tenaga kesejahteraan sosial 
kecamatan. Kemudian dilanjutkan dengan mendiskusikan hasil sosialisasi dengan para tenaga kesejahteraan kecamatan mengenai manajemen kinerja. Teknik yang digunakan dalam penyampaian sosialisasi manajemen kinerja tenaga kesejahteraan kecamatan dalam penanggulangan masalah kesejahteraan sosial di Kecamatan Karawang Barat dengan metode presentasi di depan para tenaga kesejahteraan sosial kecamatan dan melibatkannya dalam diskusi.

\section{HASIL DAN PEMBAHASAN}

Kegiatan pengabdian kepada masyarakat ini dilakukan dengan cara melakukan Sosialisasi Manajemen Kinerja Tenaga Kesejahteraan Sosial Dalam Penanggulangan Masalah Kesejahteraan Sosial di Kecamatan Karawang Barat. Hasil kegiatan pengabdiankepada masyarakat diharapkan mampu meningkatkan kinerja Tenaga Kesejahteraan Kecamatan. Dalam melakukan sosialisasi penulis menyampaikan manajemen kinerja dari Wibowo. Wibowo (2007) mengatakan manajemen kinerja adalah manajemen tentang menciptakan hubungan dan memastikan komunikasi yang efektif. Manajemen kinerja memfokuskan pada apa yang diperlukan oleh organisasi, manajer dan pekerja untuk berhasil. Manajemen kinerja adalah tentang bagaimana kinerja dikelola untuk memperoleh sukses. Berbeda dengan Wibowo, Armstrong dan Baron (Wibowo, 2007) mengatakan kinerja merupakan hasil pekerjaan yang mempunyai hubungan kuat dengan tujuan strategis organisasi, kepuasan konsumen dan memberikan kontribusi pada ekonomi. Dengan demikian, kinerja adalah tentang melakukan pekerjaan dan hasil yang dicapai dari pekerjaan tersebut. Kinerja adalah tentang apa dan bagai mana cara mengerjakannya. Penjelasan mengenai manajemen kinerja di atas diharapkan dapat dipahami oleh para pegawai tenaga kesejahteraan sosial kecamatan dalam melaksanakan tugasnya dan dapat mencapai tujuan yang telah ditentukan sebelumnya.
Manajemen kinerja bekerja atas dasar yang dapat dijadikan acuan bersama agar dapat mencapai hasil yang diharapkan. Sebagai prinsip dasar manajemen kinerja adalah bersifat:

1. Strategis

Manajemen strategi bersifat strategis dalam arti membahas masalah kinerja secara lebih luas, lebih urgent dengan tujuan jangka panjang.

2. Perumusan Tujuan

Manajemen kinerja dimulai dengan melakukan perumusan dan mengklasifikasi terlebih dahulu tujuan yang hendak dicapai organisasi.

3. Perencanaan

Perencanaan kinerja menyangkut pendefinisian tujuan dan sasaran organisasi, membangun strategi menyeluruh untuk mencapai tujuan tersebut dan mengembangkan hierarki perencanaan secara komprehensif untuk mengintegrasikan dan mmengkoordinasikan aktivitas.

4. Umpan Balik

Pelaksanaan manajemen kinerja memerlukan umpan balik terus-menerus. Umpan balik memungkinkan pengalaman dan pengetahuan penglaman dan pengetahuan yang diperoleh dari pekerjaan individu dipergunakan untuk memodifikasi tujuan organisasi.

5. Pengukuran

Setiap organisasi berkeinginan mencapai tingkat kinerja tinggi. Untuk itu perlu mengetahui perkembangan pencapaian target dan waktu yang tersedia. Pengukuran perlu dilakukan untuk mengetahui apakah pelaksanaan dapat berjalan sesuai rencana, apakah terdapat kesenjangan kinerja dan apakah hasil akhir diperkirakan dapat dicapai.

6. Perbaikan Kinerja

Perbaikan kinerja harus dilakukan karena prestasi kerja yang dicapai tidak seperti yang diharapkan. Dengan melakukan perbaikan kinerja diharapkan tujuan 
organisasi di masa depan dapat dicapai dengan lebih baik.

7. Berkelanjutan

Manajemen kinerja merupakan suatu proses yang sifatnya berlangsung secara terus-menerus, berkelanjutan, bersifat evolusioner dimana kinerja secara bertahap selalu diperbaiki sehingga menjadi semakin baik.

8. Menciptakan Budaya

Budaya merupakan kegiatan manusia yang sistematis diturunkan dari generasi ke generasi melalui berbagai proses pembelajaran untuk menciptakan cara hidup tertentu yang paling cocok dengan lingkungannya. Budaya terbentuk dari sekelompok orang terorganisasi yang mempunyai tujuan, keyaninan nilai-nilai yang sama, dapat diukur melalui pengaruhnya pada motivasi.

9. Pengembangan

Organisasi yang cerdas dan berkeinginan meningkatkan kinerjanya harus berupaya mengembangkan sumber daya manusia secara berkelanjutan. Rotasi penugasan ke bidang pekerjaan yang berbeda akan memberikan tambahan bagi tenaga kerja, karema mereka menjasi memiliki keterampilan beragam.

10. Kejujuran

Kejujuran mempunyai beberapa segi dan tindakan dan mereka menggunakan proses penilaian untuk menggali kebenaran secara luas dan dalam akan memperoleh manfaat terbesar.

11. Pelayanan

Memberitahu orang tentang apa yang mereka tidak mau mendengar dapat membuat mereka tidak bahagia. Akan tetapi, hal tersebut hanya membantu mengubah dan mendapatkan arah yang tepat. Belajar membantu orang lain dengan baik merupakan proses pembelajaran jangka panjang dimana membantu orang lain agar menjadi lebih baik dan belajar tentang apa yang dapat berjalan dan tidak dapat berjalan.
12. Tanggung Jawab

Tanggung jawab merupakan prinsip dasar dibelakang pengembangan kinerja. Dengan memahami dan menerima tanggung jawab atas apa yang mereka kerjakan dan tidak kerjakan untuk mencapai tujuan mereka.

13. Bermain

Prinsip bermain dalam manajemen kinerja orang dapat mendapatkan kepuasan dari apa yang mereka kerjakan. Apabila tidak menerapkan prinsip bermain, bekerja akan menjadi beban.

14. Rasa Kasihan

Rasa kasih merupakan prinsip bahwa manajer memahami dan empati terhadap orang lain. Kebanyakan orang yang tidak menunjukan rasa kasihan pada diri mereka sendiri.

15. Konsensus dan Kerja Sama

Manajemen kinerja mengandalkan pada konsensus dan kerja sama antara atasan dan bawahan daripada menekankan pada kontrol dan melakukan paksaan.

16. Komunikasi Dua Arah

Manajemen kinerja memerlukan gaya manajemen yang bersifat terbuka dan jujur serta mendorong terjadinya komunikasi dua arah antara atasan dan bawahan. Komunikasi dua arah menunjukan adanya sikap keterbukaan dan saling pengertian antara dua pihak.

Prinsip-prinsip dasar dari manajemen kinerja di atas, penulis sampaikan pada saat melaksanakan pengabdian kepada masyarakat dengan harapan setelah mengetahui prinsip dasar tersebut para pegawai kesejahteraan sosial kecamatan dapat menerapkannya ketika sedang bertugas dalam menanggulangi masalah kesejahteraan sosial di Kecamatan Karawang Barat. 
Tahapan Sosialisasi Manajemen Kinerja Tenaga Kesejahteraan Dalam Penanggulangan Masalah Kesejahteraan Sosial

1. Opening

Pembukaan disampaikan oleh panitia menyampaikan susunan acara selama 5 sebagai berikut:
a. Registrasi Peserta Sosialisasi
b. Pembacaan al-quraan
c. Menyanyikan Lagu Indonesia Raya
d. Sambutan Ketua Pengabdian.
e. Sambutan Camat Karawang Barat
f. Sambutan Ketua Tenaga Kerja Kesejahteraan Sosial

2. Pemateri/Narasumber

Hanny Purnamasari, S.Sos., M.A.P

Rachmat Ramdani, S.IP., M.I.Pol

3. Materi Sosialisasi

Materi Sosialisasi Manajemen Kinerja Tenaga Kesejahteraan Kecamatan Dalam Penanggulangan Kesejahteraan Sosial di Kecamatan Karawang Barat yaitu;
a. Prinsip Dasar Manajemen Kinerja
b. Manajemen Kinerja Sektor Publik
c. Tahapan-Tahapan Manajemen Kinerja Di Sektor Publik

\section{d. Closing}

4. Penutupan

Penutupan dilaksanakan selama 5 menit dengan menyampaikan simpulan hasil sosialisasi dan ditutup dengan foto bersama dengan para peserta seminar.

\section{Hasil yang Diharapkan}

Pada kegiatan pengabdian kepada masyarakat diharapkan paraTenaga Kesejahteraan Sosial Kecamatan dalam menjalankan tugas dan fungsi dapat meningkatkan manajemen kinerja dalam mencapai tujuan yang telah ditentukan. Tahapan manajemen kinerja di sektor publik Mahmudi (2005) menyatakan bahwa manajemen kinerja sektor publik mengandung prosedur, langkah-langkah dan tahapan yang membentuk suatu siklus kinerja. Adapun tahapan sistem manajemen kinerja tersebut meliputi perencanaan kinerja, tahapan pelaksanaan kinerja, tahapan penilaian kinerja, tahapan review dan tahapan perbaikan kinerja. Setelah dilaksanakan kegiatan pengabdian kepada masyarakat ini penulis berharap tenaga kesejahteraan sosial kecamatan memiliki kemampuan kognitif yaitu dapat berpikir secara cepat dan bertindak secara rasional dalam pengambilan keputusan serta dapat meningkatkan kemampuan psikomotorik untuk bekal bekerja dalam memanggulangi masalah kesejahteraan sosial di lapangan.

\section{SIMPULAN}

Dengan diadakannya kegiatan pengabdian kepada masyarakat dengan tema Sosialisasi Manajemen Kinerja Tenaga Kesejahteraan Sosial Kecamatan Dalam Penanggulangan Kesejahteraan Sosial di Kecamatan Karawang Barat, diharapkan para Tenaga Kesejahteran Sosial Kecamatan dapat meningkatkan kemampuan kognitif maupun psikomotorik dalam manajemen kinerja.

\section{SARAN}

1. Untuk meningkatkan kinerja yang optimal para tenaga kesejahteraan sosial kecamatan perlu dilakukan monitoring dan evaluasi oleh ketua tenaga kesejahteraan sosial kecamatan secara berkelanjutan.

2. Untuk mengasah kemampuan kognitif dan psikomotorik tenaga kesejahteraan sosial kecamatan pemerintah daerah diharapkan dapat memfasilitasi dengan diadakannya berbagai kegiatan agar dapat mendukung kinerja dari tenaga kesejahteraan sosial dalam menanggulangi masalah kesejahteraan sosial di lapangan.

\section{UCAPAN TERIMAKASIH}

Tim penulis mengucapkan terima kasih kepada tenaga kesejahteraan sosial Kecamatan Karawang Barat sebagai mitra pada kegiatan ini, kami juga berterimaksih kepada Lembaga Pengabdian Pada Masyarakat (LPPM) Universitas Singaperbangsa Karawang yang telah mendanai kegiatan pengabdian ini sehingga terlaksana dengan baik. 


\section{DAFTAR PUSTAKA}

Achmad S, Ruky. 2001. Sistem manajemen kinerja. Jakarta: PT. Gramedia.

Amstrong, Michael \& Angela Barong. 2007. Manajemen Kinerja Edisi Ketiga. Jakarta: PT. Raja Grafindo Persada.

Bintarsih, Sekarningrum, dkk. Sosialisasi dan Edukasi KANGPISMAN (Kurangi, Pisahkan, dan Manfaatkan Sampah). Jurnal Kumawula Volume 3 No 1 April 2020. Hal 73-86

Costello, Sheila J. 1994. Effective Performance management, New york: Mc. Graw-Hill Companies.

Dessler, Gary., 2003, Manajemen Sumber Daya Manusia. Jilid I. Edisi 10. Jakarta: PT Indeks.

Dharma, surya. 2001. Manajemen Kinerja Edisi Ketiga. Yogyakarta: Pustaka Pelajar.
Nina Kalina, dkk. Sosialisasi Pembangunan Perumahan dan Pemukinaman Berbasisi Komunitas dan Perilaku Hidup Bersih dan Sehat di Desa Polusari Kecamatan Pangalengan Kabupaten Bandung. Jurnal Kumawula Volume 3 No 2 Agustus 2020. Hal 154-162.

Williams, 1998, Kinerja Karyawan: Definisi Faktor yang Mempengaruhi dan Cara Meningkatkan Kinerja Karyawan, Jurnal SDM, Vol.1. 


\section{DOKUMENTASI KEGIATAN}

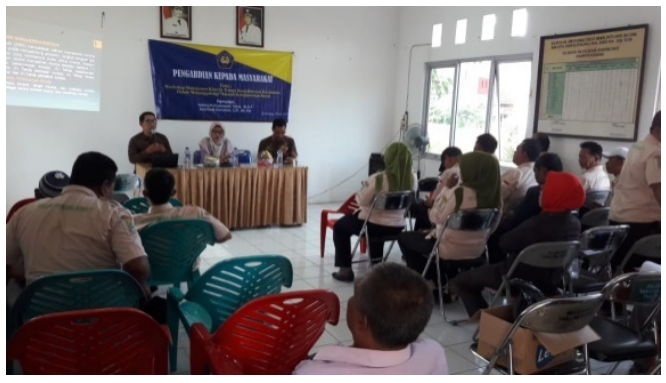

Gambar 1 sosialisasi manajemen kinerja tenaga kesejahteraan sosial kecamatan

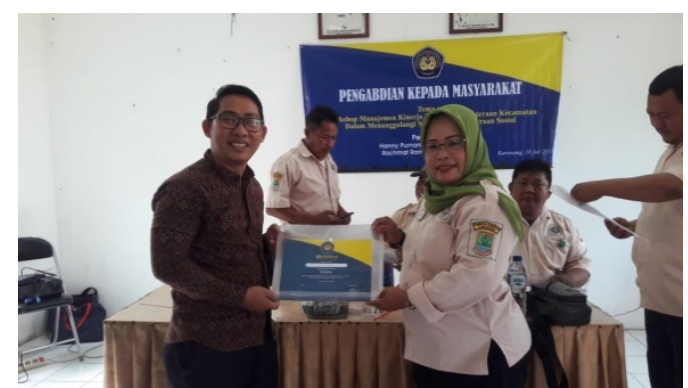

Gambar 3 Penyerahan seminar kit dan sertifikat

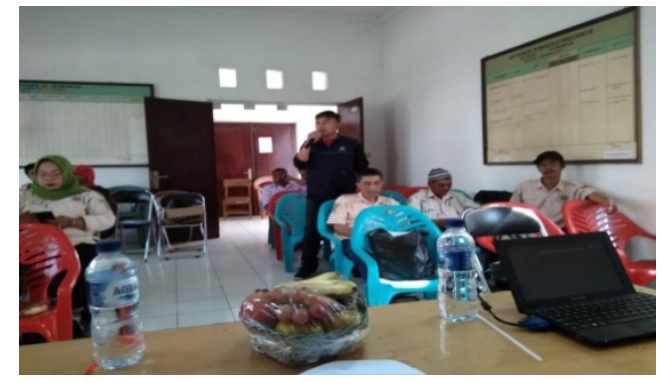

Gambar 2 Sesi tanya jawab tentang manajemen kinerja

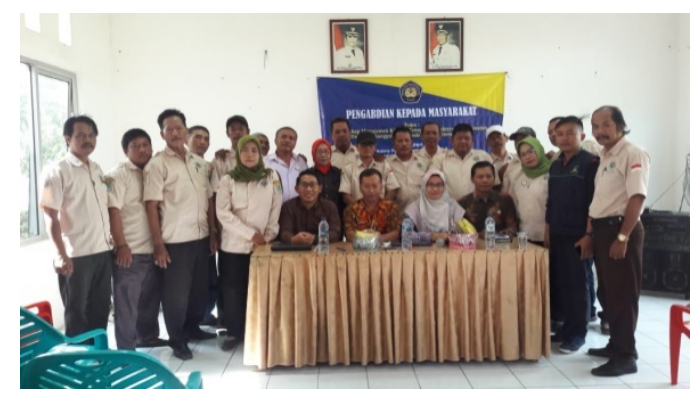

Gambar 4 Foto berasama peserta sosialisasi manajemen kinerja 